\title{
Larval fish in the surf zone of Pontal do Sul beach, Pontal do Paraná, Paraná, Brazil
}

\author{
Rodrigo Santiago Godefroid ${ }^{1}$ \\ Marion Hofstaetter ${ }^{1}$ \\ Henry Louis Spach ${ }^{1}$
}

\begin{abstract}
A total of 6,575 larvae in the preflexion, flexion and post-flexion stages of 15 families, 26 genera and 29 species were captured in the surf zone of Pontal do Sul beach, Paraná, Brazil. Samples of the families Gerreidae and Scianidae predominated and larvae of Eucinostomus argenteus (Baird\&Girard, 1854), Micropogonias furnieri (Desmarest, 1823), Eucinostomus gula (Cuvier, 1830), Menticirrhus americanus (Linnaeus, 1758) and Anchoa tricolor (Agassiz, 1829) were the most dominant species. Greater abundance of larvae was observed during the summer, followed by winter and in a less extent during spring and autumn. The number of species was greater in the summer, and there were no significant differences in the rest of the seasons.

KEY WORDS. Ichthyoplankton, surf zone, Brazil
\end{abstract}

The movement of larvae from the spawning areas to the coast of fish recruited to estuarine areas, occurs initially by passive drift (ROSENBERG 1982; MiLleR et al. 1984), with the majority of larvae being in the planktonic stage. After the aggregation of larvae in coastal areas, such as beaches, a migration towards the estuaries occurs (ROSENBERG 1982; MiLLER et al. 1984), generally in advanced stages near or after metamorphose, as was observed in different orders of fish (WEINSTEIN et al. 1980).

Despite the importance of studies on ichthyoplankton in the south-southeast Brazilian coast, these were for the most part performed on the continental shelf, being a fairly limited number of works in coastal areas. Concerning the beach environment, recognized as nursery areas, information on fish larvae is practically non-existent. This is due in part to the fact that in the majority of surveys on the ichthy ofauna of the surf zone the the nets design and mesh did not allow the sampling of this important part of the local fish assemblage. Therefore this study reports the abundance, diversity and seasonability of the fish larvae of the surf zone at Pontal do Sul beach, a sandy beach situated in the Galheta Inlet of Paranaguá Bay (253' $20^{\prime \prime} \mathrm{S}, 48^{\circ} 20^{\prime} 48^{\prime \prime} \mathrm{W}$ ), southern Brazil.

\section{MATERIALS AND METHODS}

Samples were obtained from the surf zone at Pontal do Sul beach, between May 1993 and April 1994, through bi-monthly collections in high and low tides (daytime and nightime) of the new and full moon. Sixteen monthly tows were performed, eight with a conical plankton net (mesh size $300 \mu \mathrm{m}$ and a mouth

1) Centro de Estudos do Mar, Universidade Federal do Paraná. Avenida Beira Mar,Pontal do Sul, 83255-000 Pontal do Paraná, Paraná, Brasil 
diameter of $60 \mathrm{~cm}$ ) and eight with a beach seine (mesh size of $1 \mathrm{~mm}, 18 \mathrm{~m}$ in length and $2 \mathrm{~m}$ in height), in the same direction as the current, at a depth which never surpassed $1.70 \mathrm{~m}$ along a $100 \mathrm{~m}$ strip paralel to the beach. Data of salinity and surface water temperature were collected at the same time.

Samples were preserved in the field with $4 \%$ buffered formalin. All fish larvae were sorted, identified to the lowest possible taxon and classified according to their development stage (AHLSTRON \& BALL 1954). The seasons were defined in the following way: September to November=spring; December to February=summer; March to May=autumn and June to August=winter.

\section{RESULTS}

\section{Conical Plankton Net}

A total of 649 fish larvae were captured, comprising 9 families, 13 genera and 12 species. The Sciaenidae and Gobiidae families were the most numerous in terms of species (three species each), followed by the Gerreidae (two species). Considering only the identified larvae, the families Gerreidae, Gobiidae and Sciaenidae dominated numerically, while the rest represented only $9.59 \%$. Regarding the species composition, $85.5 \%$ (555 individuals) was not identified as genera, $11.9 \%$ was made up by Eucinostomus argenteus (Baird \& Girard, 1854), Gobionellus spp. and Micropogonias furnieri (Desmarest, 1823), and Elops saurus (Linnaeus, 1766), Anchoa tricolor (Agassiz, 1829), Paraexocoetus brachypterus (Richardson, 1846), Eucinostomus gula (Currer, 1830), Menticirrhus littoralis (Holbrook, 1860), Menticirrhus spp., Umbrina coroides (Cuvier, 1830), Bathygobius soporator (Valenciennes, 1837), Microgobius spp., Mugil curema (Desmarest, 1831), Etropus crossotus (Jordan \& Gilbert, 1882) and Achirus lineatus (Linnaeus, 1758 ) contributed only with $2.6 \%$ of the total (Tab. I). Larvae in the post-flexion stage occurred in all the identified species while the pre-flexion stage was present in non-identified larvae and in M. furnieri, and the flexion stage occurred only in A. tricolor.

Considering the seasonal occurrence, larvae of M. littoralis, Menticirrhus spp., U. coroides, Microgobius spp. and E. crossotus were caught over the winter, while E. saurus, E. gula, M. curema and A. lineatus occurred only in the summer and $P$. brachypterus only in spring. Other taxa were represented in more than one season as was the case of $E$. argenteus, captured since the beginning of summer until the beginning of winter, M. furnieri, which occurred in winter, spring, and summer, Gobionellus spp., recorded during autumn and winter, A. tricolor, present in spring and summer, and $B$. soporator, collected during winter and summer (Tab. I).

Larvae of A. tricolor, B. soporator, Gobionellus spp., E. crossotus and $M$. furnieri were present in water with salinity between 27 and 35, while E. argenteus ocurred in a greater range of salinity. Larvae of M. furnieri and $E$. argenteus were captured in water with a greater range of temperature, while $A$. tricolor, B. soporator, Gobionellus spp. and E. crossotus were caught over a smaller range of temperature (Tab. I). 
Table I. General data on fish larvae capture with plankton conical net in the surf zone of the beach at Pontal do Sul, between May 1993 and April 1994. (Y) Yolk-sac larvae, (PRF) preflexion, $(F)$ flexion, $(\mathrm{PF})$ post-flexion.

\begin{tabular}{|c|c|c|c|c|c|c|}
\hline Taxon & $\begin{array}{c}\text { Number } \\
\text { individuals }\end{array}$ & $\begin{array}{c}\text { Capture } \\
(\%)\end{array}$ & Stage & Season & $\begin{array}{c}\text { Temperature } \\
\text { range }\end{array}$ & $\begin{array}{l}\text { Salinity } \\
\text { range }(\% \circ)\end{array}$ \\
\hline \multicolumn{7}{|l|}{ Elopidae } \\
\hline Elops saurus & 1 & 0.15 & PF & Summer & 26.0 & 30.0 \\
\hline \multicolumn{7}{|l|}{ Engraulidae } \\
\hline Anchoa tricolor & 3 & 0.46 & $F / P F$ & Spring, Summer & $22.0-25.0$ & $27.0-34.0$ \\
\hline \multicolumn{7}{|l|}{ Exocoetidae } \\
\hline Paraexocoetus brachypterus & 1 & 0.15 & $\mathrm{PF}$ & Spring & 21.5 & 28.5 \\
\hline \multicolumn{7}{|l|}{ Gerreidae } \\
\hline Eucinostomus argenteus & 51 & 7.8 & $\mathrm{PF}$ & Summer, Autumn, Winter & $18.0-26.0$ & $21.0-34.0$ \\
\hline Eucinostomus gula & 1 & 0.15 & PF & Summer & 26.0 & 30.0 \\
\hline \multicolumn{7}{|l|}{ Sciaenidae } \\
\hline Menticirrhus littoralis & 1 & 0.15 & PF & Winter & 16.0 & 33.0 \\
\hline Menticirrhus spp. & 1 & 0.15 & PF & Winter & 21.0 & 29.0 \\
\hline Micropogonias furnieri & 8 & 1.23 & PRF / PF & Spring, Summer, Winter & $16.0-26.0$ & $30.0-35.0$ \\
\hline Umbrina coroides & 1 & 0.15 & PF & Winter & 15.0 & 29.00 \\
\hline \multicolumn{7}{|l|}{ Gobiidae } \\
\hline Bathygobius soporator & 3 & 0.46 & PF & Summer, Winter & $21.0-25.0$ & $29.0-34.0$ \\
\hline Gobionellus spp. & 18 & 2.77 & PF & Autumn, Winter & $20.0-23.0$ & $29.0-34.0$ \\
\hline Microgobius spp. & 1 & 0.15 & PF & Winter & 20.0 & 34.0 \\
\hline \multicolumn{7}{|l|}{ Mugilidae } \\
\hline Mugil curema & 1 & 0.15 & $\mathrm{PF}$ & Summer & 26.0 & 30.0 \\
\hline \multicolumn{7}{|l|}{ Paralichthyidae } \\
\hline Etropus crossotus & 2 & 0.30 & $\mathrm{PF}$ & Winter & $20.0-21.0$ & $29.0-35.0$ \\
\hline \multicolumn{7}{|l|}{ Achiridae } \\
\hline Achirus lineatus & 1 & 0.15 & PF & Summer & 28.0 & 31.0 \\
\hline Not identify & 555 & 85.51 & Y /PRF / PF & All seasons & $16.0-31.0$ & $23.0-35.0$ \\
\hline
\end{tabular}

\section{Beach Seine Net}

A total of 5,926 fish larvae in the post-flexion stage of 12 families, 20 genera and 25 species were captured. A greater number of species occurred in the family Sciaenidae, represented in the samples by seven species. The capture was comprised, for the most part, by Gerreidae $(81.68 \%)$ and Sciaenidae $(13.98 \%)$ with the other families conprising only $4.34 \%$ of the total. The most abundant species were $E$. argenteus (66.88\%), M. furnieri (6.22\%), E. gula (4.23\%), M. americanus $(3.98 \%)$ and $A$. tricolor $(2.00 \%)$ with the 20 remaining species corresponding to only $16.67 \%$ of the total (Tab. II).

Larvae of Albula vulpes (Linnaeus, 1758), Anchoa parva (Fowler, 1976), Adenops dissimilis (Carvalho, 1956), E. gula, Bairdiella ronchus (Cuvier, 1830) and Polydactylus virginicus (Linnaeus, 1758) were present in the summer, while Opisthonema oglinum (Lesueur, 1818) and Oligoplites saurus (Bloch \& Schneider, 1801) appeared in autumn. Cynoscion leiarchus (Cuvier, 1830) and Polydactylus oligodon (Günther, 1860) were exclusively caught during the winter, and Hyporhamphus unifasciatus (Ranzani, 1842) and M. littoralis during the spring. Larvae of Glossanodon pygmaeus (Cohen, 1958), Trachinotus carolinus (Linnaeus, 1766), Umbrina canosai (Berg, 1895), U. coroides, Harengula jaguana (Poey, 1865), Sardinella brasiliensis (Steindacner, 1789), E. argenteus, M. curema and Mugil gaimardianus (Desmarest, 1831) were observed in two seasons of the year. A. tricolor, $M$. americanus and $M$. furnieri occurred throughout the seasons, the former being more abundant in the summer and the latter two more abundant in the winter (Tab. II). 
Larvae of E. saurus, A. tricolor, E. argenteus, $M$. americanus, $M$. furnieri, $U$. coroides and $M$. gaimardianus were captured in water with great variation in salinity and temperature. Larvae of H. jaguana, E. gula and M. curema were caught in water with great variation in salinity but not in temperature (Tab. II).

Table II. General data on fish larvae capture with beach seine in the surf zone of the beach at Pontal do Sul, between May 1993 and April 1994 (PF) Post-flexion.

\begin{tabular}{|c|c|c|c|c|c|c|}
\hline Taxon & $\begin{array}{c}\text { Number } \\
\text { individuals }\end{array}$ & $\begin{array}{c}\text { Capture } \\
(\%)\end{array}$ & Stage & Season & $\begin{array}{l}\text { Temperature } \\
\text { range }\end{array}$ & $\begin{array}{l}\text { Salinity } \\
\text { range (\%o) }\end{array}$ \\
\hline \multicolumn{7}{|l|}{ Elopidae } \\
\hline Elops saurus & 21 & 0.300 & PF & Spring, Summer, Winter & $15.0-27.0$ & $25.0-35.0$ \\
\hline \multicolumn{7}{|l|}{ Albulidae } \\
\hline Albula vulpes & 20 & 0.300 & PF & Summer & $26.5-27.0$ & $31.0-32.0$ \\
\hline \multicolumn{7}{|l|}{ Engraulidae } \\
\hline Anchoa parva & 2 & 0.003 & PF & Summer & $25.0-26.5$ & $31.0-32.0$ \\
\hline Anchoa tricolor & 119 & 2.000 & PF & All seasons & $20.0-30.0$ & $28.0-34.0$ \\
\hline \multicolumn{7}{|l|}{ Clupeidae } \\
\hline Brevoortia spp. & 1 & 0.001 & PF & Autumn & 22.0 & 32.0 \\
\hline Harengula clupeola & 29 & 0.400 & PF & Summer, Autumn & $25.0-27.0$ & $19.0-31.0$ \\
\hline Opistonema oglinum & 2 & 0.003 & PF & Autumn & $22.0-27.0$ & $29.0-32.0$ \\
\hline Sardinella brasiliensis & 3 & 0.050 & PF & Summer, Autumn & $25.0-27.0$ & $29.0-31.0$ \\
\hline \multicolumn{7}{|l|}{ Argentinidae } \\
\hline Glossanodon pygmaeus & 3 & 0.005 & PF & Spring, Summer & $22.0-25.0$ & $28.0-31.0$ \\
\hline \multicolumn{7}{|l|}{ Atherinidae } \\
\hline Adenops dissimilis & 1 & 0.010 & PF & Summer & 25.0 & 34.0 \\
\hline \multicolumn{7}{|l|}{ Exocoetidae } \\
\hline Hyporhamphus unifasciatus & 3 & 0.050 & PF & Spring & $22.0-23.5$ & $28.0-29.0$ \\
\hline \multicolumn{7}{|l|}{ Carangidae } \\
\hline Oligoplites saurus & 1 & 0.001 & PF & Autumn & 25.0 & 27.0 \\
\hline Trachinotus carolinus & 2 & 0.020 & PF & Spring, Summer & $22.0-25.0$ & $30.0-31.0$ \\
\hline \multicolumn{7}{|l|}{ Gerreidae } \\
\hline Eucinostomus argenteus & 3965 & 66.880 & PF & Summer, Autumn & $25.5-28.0$ & $25.0-32.0$ \\
\hline Eucinostomus gula & 251 & 4.230 & PF & Summer & $25.0-27.5$ & $25.0-32.0$ \\
\hline Eucinostomus spp. & 627 & 10.570 & PF & Summer, Autumn & $22.0-27.5$ & $19.0-34.0$ \\
\hline \multicolumn{7}{|l|}{ Sciaenidae } \\
\hline Baidiella ronchus & 3 & 0.050 & PF & Summer & 26.0 & 25.0 \\
\hline Cynoscion leiarchus & 2 & 0.030 & PF & Winter & 15.0 & 29.0 \\
\hline Menticirrhus americanus & 234 & 3.980 & PF & All seasons & $15.0-26.0$ & $26.0-34.0$ \\
\hline Menticirrhus littoralis & 8 & 0.130 & PF & Spring & 23.0 & 30.0 \\
\hline Menticirrhus spp. & 208 & 3.509 & PF & Spring, Summer, Winter & $15.0-25.0$ & $29.0-35.0$ \\
\hline Micropogonias furnieri & 369 & 6.220 & PF & All seasons & $15.0-25.0$ & $28.0-35.0$ \\
\hline Umbrina canosai & 2 & 0.020 & PF & Spring, Summer & 23.0 & 30.0 \\
\hline Umbrina coroides & 3 & 0.005 & PF & Summer, Winter & $15.0-25.0$ & $29.0-35.0$ \\
\hline \multicolumn{7}{|l|}{ Polynemidae } \\
\hline Polydactylus oligodon & 1 & 0.010 & PF & Winter & 15.0 & 29.0 \\
\hline Polydactylus virginicus & 1 & 0.010 & PF & Summer & 27.0 & 32.0 \\
\hline \multicolumn{7}{|l|}{ Mugilidae } \\
\hline Mugil curema & 8 & 0.130 & PF & Summer, Autumn & $26.0-27.5$ & $25.0-31.0$ \\
\hline Mugil gaimardianus & 31 & 0.520 & PF & Summer, Autumn & $26.0-30.0$ & $25.0-35.0$ \\
\hline Mugil spp. & 6 & 0.100 & PF & Summer, Autumn & $26.0-30.0$ & $23.0-35.0$ \\
\hline
\end{tabular}

\section{DISCUSSION}

This was the first study on beach ichthyoplankton in the south and southeast Brazilian coast. In the studied area, 35 taxa were captured, namely, 26 genera and 29 species of 15 families of fish larvae. In the post-flexion stage, these are new citations for the area: E. saurus, A. vulpes, A. parva, Brevoortia spp., O. oglinum, G. pygmaeus, A. dissimilis, T. carolinus, E. argenteus, E. gula, B. ronchus, $C$. leiarchus, $M$. littoralis, U. canosai, $U$. coroides, $P$. oligodon, $P$. virginicus, $M$. 
curema, M. gaimardianus, P. brachypterus, B. soporator, Gobionellus spp., Microgobius spp. and E. crossotus. Except for the genera Gobionellus and Microgobius and the species $U$. canosai, the other taxa had not previously been cited in the larval stage in the southern Brazilian coast.

A review of the available literature on the subject showed that, up to the present time, it has been cited for the Paraná coast 14 species of fish larvae in the region of the continental shelf (MATSUURA 1977; MATSUURA \& SATO 1981; MATSUURA \& KATSURAGAWA 1981; VALENTIN et al. 1994) and 16 species in the estuarine region (CARVAlHo 1945; SINQUE 1989; AlmeIDA \& SPACH 1992). The obtained results of this work represent an increase of $48 \%$ in the number of species of identified larvae in the Paraná coast as a whole. This contribution is even more significant when we consider separately the sectors of the shelf and of the estuary, in both cases the number is superior to $60 \%$.

SINQUE et al. (1982) and SINQUE (1989), studying the ichthyoplankton of Paranaguá Bay, observed greater abundance of eggs and fish larvae in spring and summer, followed by autumn, and smaller abundance in winter. This same seasonal pattern of numerical dominance of eggs and fish larvae was observed in the Galheta Inlet, just in front of the sampled beach and in the Laranjeiras and Guaraqueçaba Bays, in the northern portion of the Paranaguá estuary (SPACH per.com). In this study, the summer capture represented more than $80 \%$ of the total, with E. argenteus and $E$. gula contributing with more than $90 \%$ of the summer capture and around $75 \%$ of the total sampled larvae for this study. Different from the precited works, in the surf zone of the beach at Pontal do Sul the spring along with autumn showed the smaller number of individuals, while in the winter it was observed the second greatest abundance. As was the case in the summer, in which the majority of larvae were from one specie, in the spring M. furnieri represented more than $90 \%$ of the total, and in winter M. americanus and M. furnieri contributed with more than $75 \%$ of the capture.

MUELBERT \& WeISS (1991), studying the abundance and distribution in the area of the inlet to the Lagoa dos Patos estuary, found larvae throughout the year, however, with greater abundance and diversity in the spring and summer seasons. A greater diversity in spring and summer was also observed in the surf zone of the Northern Gulf of Mexico Barrier Island (RUPLE 1984). SENTA \& KinOSHITA (1985), in a survey of 55 points on the Japanese coast, observed differences between larval ichthyofauna of beach habitat and other close biotypes, especially in relation to the coastal region. They also observed a greater diversity in spring and summer. In the present work, the diversity was greater in the summer, but there was no significant difference between the other seasons of the year.

With the exception of yolk-sac larvae, sampled with the plankton net, which were probably transported outside and inside the estuary by currents, the majority of sampled larvae at Pontal do Sul beach were in the post-flexion stage, therefore, in an advanced larval development stage, which corresponds to what would be expected for an area located at the entrance of an estuary. In the majority of larval species in the post-flexion, the fins were already formed permitting an active locomotion. 
The principle of natural selection makes it possible to state that the objective of an individual is to maximize the production of its offspring. Although differences exist between this work and literature in general, it was observed that, similar to the majority of other studies of the area, there is a preference for hatching in warmer periods. In warmer seasons of the year, the presence of more favorable alimentary conditions in the estuarine region as well as in the coast, favors gonadal maturing of the fish and the feeding of the larvae.

ACKNOWLEDGEMENTS. The authors are particularly grateful to the researchers and personnel of the Centro de Estudos do Mar, Universidade Federal do Paraná who, directly or indirectly, contributed to the completion of this work.

\section{REFERENCES}

AHLSTRON, E.H. \& L. BALL. 1954. Description of eggs and larvae of jack mackerel (Trachurus symmetricus) and distribution and abundance of larvae in 1950 and 1951. U.S. Fish Widl. Serv. Fish. Bull. 56: 209-245.

AlmeIDA, M.V.O. \& H.L. SPACH. 1992. Ictioplâncton do litoral do Paraná/BrasilUma revisão. Arq. Biol. Tecnol., Curitiba, 35 (2): 221-238.

Carvalho, J.P. 1945. Copépodos de Caiobá e Baía de Guaratuba. Arq. Mus. Paranaense, Curitiba, 4 (3): 83-116.

MAtsuURA, Y. 1977. A study of the life history of Brazilian sardine, Sardinella brasiliensis. IV. Distribution and abundance of sardine larvae. Bol. Inst. oceanogr., São Paulo, 26 (2): 219-283.

MatsuURA, Y. \& G. SATO. 1981. Distribution and abundance of Scombrid larvae in southern brazilian waters. Bull. Mar. Sci. 31 (4): 824-832.

MATSUURA, Y.\& M. KATSURAGAWA. 1981. Larvae and juveniles of grey tiggerfish Balistes capriscus, from southern Brazil. Jpn Jour. Icthyol. 28 (3): 267-275.

Miller, J.M.; J.P. ReEd \& L.J. PietrafesA. 1984. Patterns, mechanisms, and approaches to the study of migrations of estuarine-dependent fish larvae and juveniles, p.209-225. In: J.D. MCClAvE; G.P. ARNOLD; J.J. DODSON \& W.H. NEILL (Eds). Mechanisms of migration in fishes. New York, Plenum.

MuelbeRT, J.H. \& G. Weiss. 1991. Abundance and distribution of fish larvae in the channel area of the Patos Lagoon Estuary, Brazil, p.43-54. In: R.D. HoyT (Ed.). Larval fish recruitment and research in the Americas: proceedings of the thirteenth annual fish conference. NOAA Tech. Rep. NMFS 95.

Rosenberg, A.A. 1982. Growth of juvenile english sole, Parophrys vetulus, in estuarine and open coastal nursery areas. Fish. Bull. 80: 245-252.

RUPLE, D. 1984. Occurence of larval fishes in the surf zone of a nothern Gulf of Mexico barrier Island. Est. Coast. Shelf Sci. 18: 191-208.

SENTA, T. \& I. KINOSHITA. 1985. Larval and juvenile fishes occurring in surf zones of western Japan. Trans. Amer. Fish. Soc. 114: 609-618.

SINQUE, C. 1989. Ictioplâncton do ecossistema da Baía de Paranaguá (Paraná Brasil). Arq. Biol. Tecnol., Curitiba, 32 (3): 473-490.

SINQUE, C.; S. KoBlitZ \& L.M. CosTA. 1982. Ictioplâncton do complexo estuarino

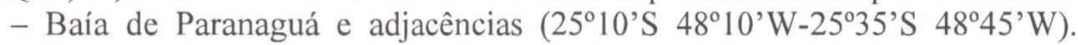


Paraná, Brasil. I - Aspectos gerais. Arq. Biol. Tecnol., Curitiba, 25 (3/4): 279-300.

Valentin, J.L; S.A Gaeta; H.L. Spach; M.A. Montú \& C. Odebrecht. 1994. Diagnóstico ambiental oceânico e costeiro das regiões sul e sudeste-Oceanografia Biológica: Plâncton. Brasília, Petrobrás, Vol. 4, 321p. WeinsteIn, M.P.; R.G Weiss; R.G. HodSON \& L.R. GERRY. 1980. Retention of three taxa of postlarval fishes in an intensively flushed tidal estuary, Cape Fear River. Nor. Caro. Fish. Serv. Fish. Bull. U.S. 78: 419-436.

Recebido em 19.III.1998; aceito em 16.IX.1999. 